Recommended by Doctor of Pharmacy, Professor O. M. Koshevoy

UDC $615.1 \quad 615.32581 .8$

https://doi.org/10.24959/nphj.18.2211

Yu. B. Kerimov, D. I. Isaev, E. G. Kerimli, E. Yu. Akhmedov*

Azerbaijan Medical University

*National University of Pharmacy

\title{
The pharmacognostic study of the aerial part of Prangos ferulacea lindl. at the stage of the beginning of vegetation
}

Aim. To study the coumarin composition of salted Prangos ferulacea herb collected at the stage of vegetation and compare it with the coumarin composition of the freshly collected raw material.

Materials and methods. The analysis was performed using Agilent $5977 \mathrm{GC}$ and $7890 \mathrm{~B}$ MS devices. The carrier gas was helium with a constant flow of $1 \mathrm{ml} / \mathrm{min}$. The data of NIST library of standard mass-spectra were used to identify compounds.

Results and discussion. The results of the study of coumarin derivatives in the food additive prepared from Prangos ferulacea herb collected at the beginning of the vegetation period are presented. The anatomical structure of the aerial part of Prangos ferulacea has been studied, and the diagnostic features of the plant raw material have been identified.

Conclusions. The composition of coumarin derivatives in the food additive and in the freshly collected aerial part is identical. The diagnostic features of the structure of the plant raw material of Prangos ferulacea have been identified.

Key words: Prangos; coumarins; gas chromatography-mass spectrometry; microscopy

Ю. Б. Керімов, Д. І. Ісаєв, Е. Г. Керімлі, Е. Ю. Ахмедов

Фармакогностичне дослідження надземної маси Prangos ferulacea lindl. в стадії початку вегетації

Мета роботи - вивчити кумариновий склад засоленої трави Prangos ferulacea, заготовленої у стадії вегетації, і порівняти його з кумариновим складом свіжозаготовленої сировини.

Матеріали та методи. Аналіз проводили на Agilent 5977 GC і мас-спектрометрі газової хроматографії 7890B MS. Газ-носій - гелій з постійним потоком 1,0 мл/хв. Для ідентифікації сполук використовували дані бібліотеки стандартних мас-спектрів NIST.

Результати та їх обговорення. Наведені результати вивчення похідних кумарину в харчовому продукті, виготовленому з трави Prangos ferulacea, заготовленої на початку вегетаційного періоду. Вивчено анатомічну будову надземної частини Prangos ferulacea і встановлені діагностичні ознаки будови рослинної сировини.

Висновки. Склад похідних кумарину в дієтичній добавці і свіжозаготовленій надземній масі ідентичний. Встановлені діагностичні ознаки будови сировини Prangos ferulacea.

Ключові слова: прангос; кумарини; мас-спектрометрія газовою хроматографією; мікроскопія

Ю. Б. Керимов, Д. И. Исаев, Э. Г. Керимли, Э. Ю. Ахмедов

Фармакогностическое изучение надземной массы Prangos ferulacea lindl. в стадии начала вегетации

Цель работы - изучить кумариновый состав засоленной травы Prangos ferulacea, заготовленной в стадии вегетации, и сравнить его с кумариновым составом свежезаготовленного сырья.

Материалы и методы. Анализ проведен на Agilent 5977 GC и масс-спектрометре газовой хроматографии 7890B MS. Газ-носитель - гелий с постоянным потоком 1 мл/мин. Для идентификации соединений использованы данные библиотеки стандартных масс-спектров NIST.

Результаты и их обсуждение. Приведены результаты изучения производных кумарина в пищевом продукте, приготовленном из травы Prangos ferulacea, заготовленной в начале вегетационного периода. Изучено анатомическое строение надземной части Prangos ferulacea, установлены диагностические признаки растительного сырья.

Выводы. Состав производных кумарина в диетической добавке и свежезаготовленной надземной массе идентичны. Установлены диагностические признаки строения сырья Prangos ferulacea.

Ключевые слова: прангос; кумарины; масс-спектрометрия газовой хроматографией; микроскопия 
The representatives of Apiaceae family, and in particular Prangos genus, are characterized by the content of essential oils, coumarins, furocoumarins and other substances $[1,2]$. Coumarins and furocoumarins of Prangos species have a variety of pharmacological properties [1, 3, 4]. Prangos genus in the flora of Azerbaijan are represented by five species [5]. Since olden times in early spring the local population prepare a food additive (pickle) under the name of "chashir" and a water distillate (chashir aragy) from the aerial part of Prangos ferulace, they are used to improve digestion, as well as in spasms in the abdominal area [6]. The chemical composition of this food additive is unknown; therefore, the aim of our work is to study the coumarin composition of salted Prangos ferulacea herb collected at the stage of vegetation and compare it with the coumarin composition of the freshly collected raw material. To determine the diagnostic signs of Prangos ferulacea herb it was necessary to study its anatomical structure.

\section{Materials and methods}

The analysis was performed using Agilent 5977 GC and 7890B MS devices. The column size was $30 \mathrm{~m}$ with the internal diameter of $0.25 \mathrm{~mm}$, and the film thickness of the stationary phase was $0.25 \mu$ (HP-5 MS Ultra Inert).
The carrier gas was helium with a constant flow of $1 \mathrm{ml} / \mathrm{min}$. The initial temperature of $80^{\circ} \mathrm{C}$ maintained for $5 \mathrm{~min}$, then for each minute the temperature increased by $20^{\circ} \mathrm{C}$, reached $220{ }^{\circ} \mathrm{C}$ and retained for $4 \mathrm{~min}$; after that there was the programmed rise in temperature up to $5^{\circ} \mathrm{C} / \mathrm{min}$ to a constant temperature of $280^{\circ} \mathrm{C}$. The data of NIST library of standard mass-spectra were used to identify compounds (Table).

The microscopic examination of the anatomical structure and detection of diagnostic features were performed using the known methods [7].

\section{Results and discussion}

After concentration the alcoholic extract of the aerial part of Prangos ferulacea herb collected at the stage of vegetation was treated with hexane. Then it was analyzed by the method of gas chromatography-mass spectrometry. As it can be seen from Table, this extract contains 14 components, 7 of them refer to coumarin compounds: isopsoralen; $2 \mathrm{H}, 8 \mathrm{H}-$ benzo[1,2-b:5,4-b']dipyran2-one,8,8-dimethyl-; 2-isopropenyl-2,3-dihydrofuro[3,2-g] chromen-7-one; 2-(1-hydroxy-1-methylethyl)-2,3-dihydrofuro[3,2-g] chromen-7-one; (S)-7-hydroxy-8,8-dimethyl7,8-dihydropyrano(3,2-g)chromen-2(6H)-one; $2 \mathrm{H}$-1-benzopyran-2-one, 6-(2,3-dihydroxy-3-methylbutyl)-

Table

Chemical compounds of the amount of extractives of the Prangos ferulacea aerial part at the beginning of the vegetation period

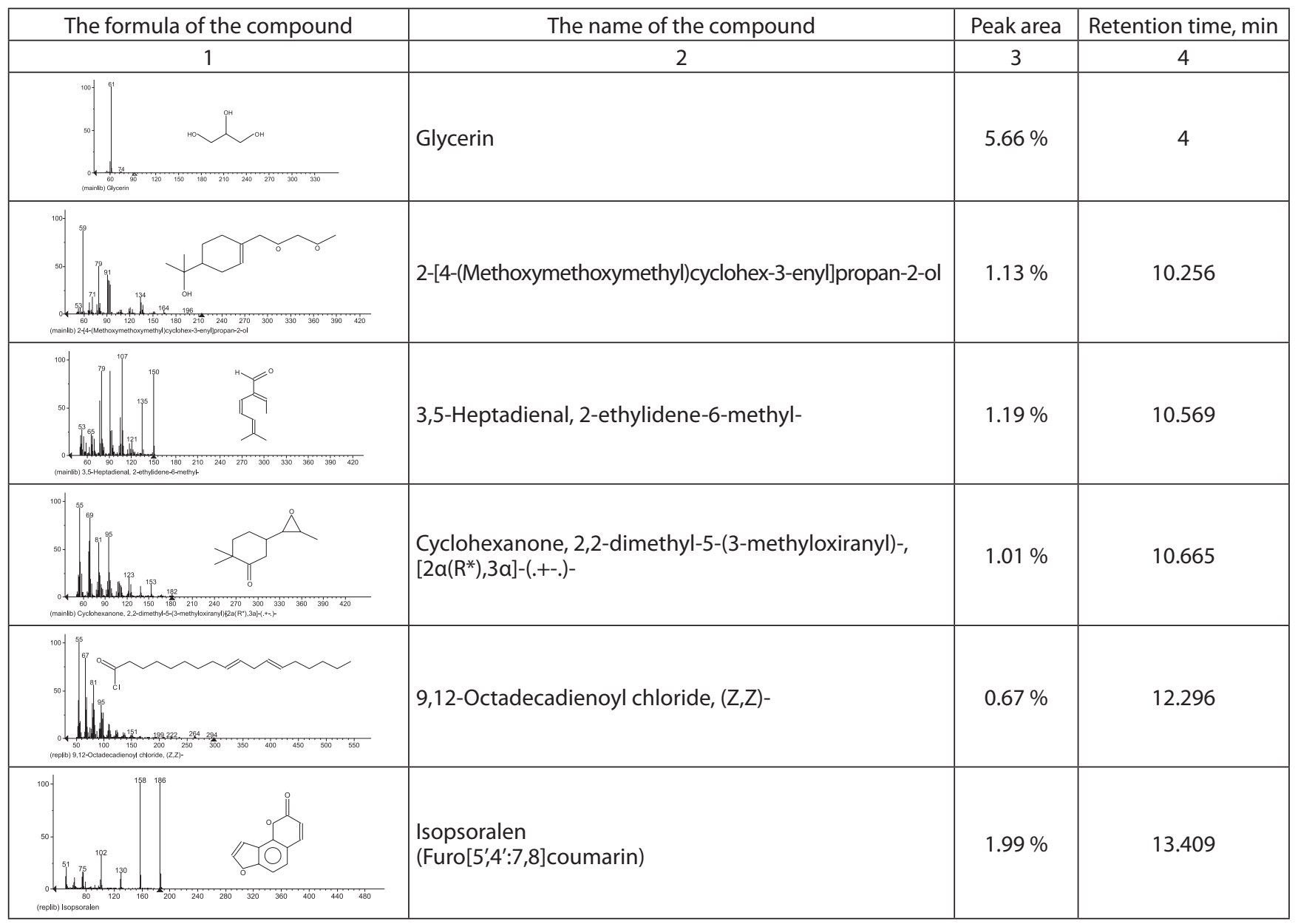


Continuation of Table

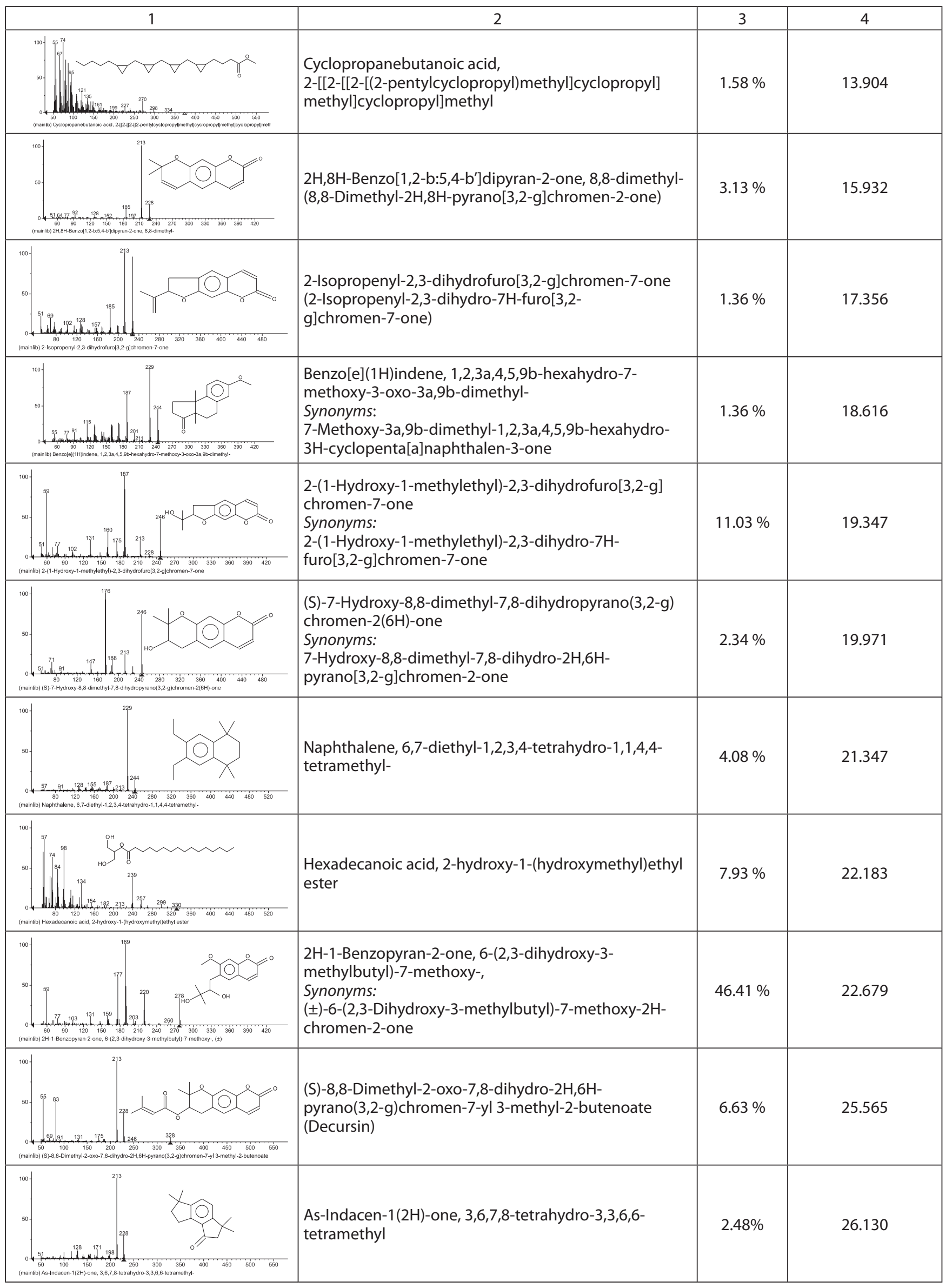




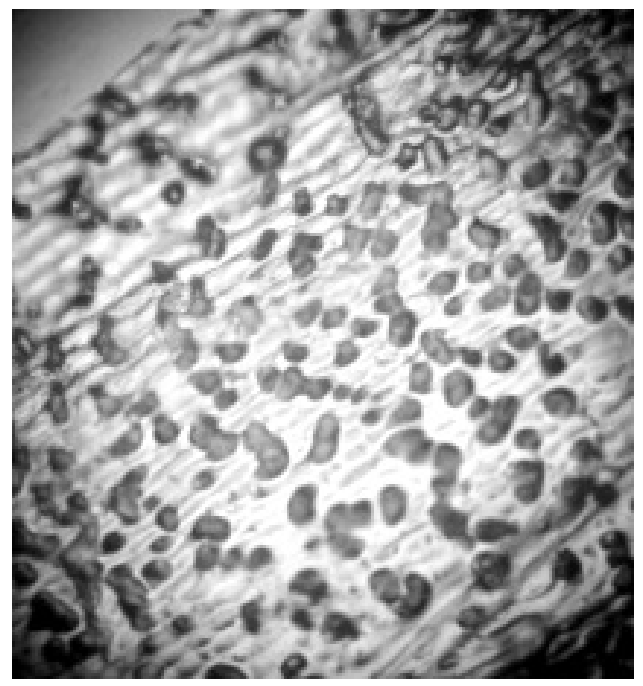

Fig. 1. Glands on the epidermis of the stem

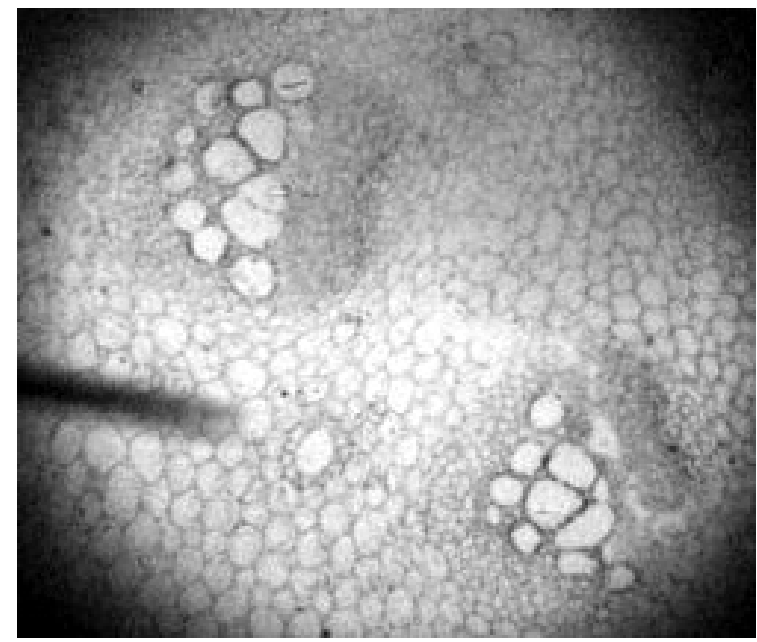

Fig. 2. Schizogenic spaces and vascular bundles on the cross section of the stem

7-methoxy-; (S)-8,8-dimethyl-2-oxo-7,8-dihydro-2H, 6H-pyrano(3,2-g)chromen-7-yl; 3-methyl-2-butenoate. In percentage terms such coumarin derivatives as $2 \mathrm{H}-1$-benzopyran-2-one,6-(2,3-dihydroxy-3-methylbutyl)-7-methoxy- (46.41 \%); 2-(1-hydroxy-1-methylethyl)- 2,3-dihydrofuro[3,2-g]chromen-7-one (11.03\%) prevail. The remaining 10 components belong to different classes of compounds.

There is a large number of glands on the epidermis of the stem (Fig. 1). On the cross section of the stem along the entire surface of the cut there are clearly visible schizogenic spaces and vascular-fibrous bundles of the closed type where the layer of cambium between the phloem and xylem is absent (Fig. 2). The glands consist of a stalk and a spiked round top (Fig. 3).

On the cross section of the leaf the large and small vascular bundles surrounded by the magnocellular parenchyma and a schizogenic space are observed (Fig. 4).

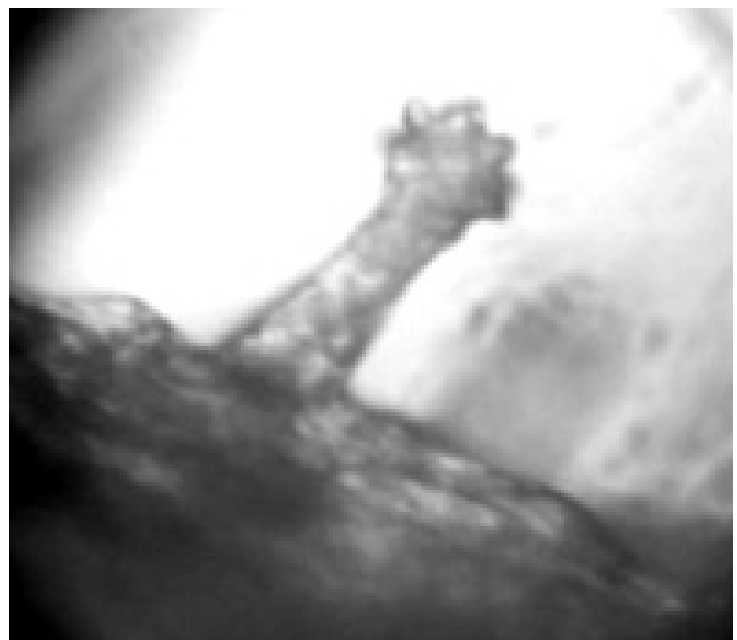

Fig. 3. A gland on the leaf surface

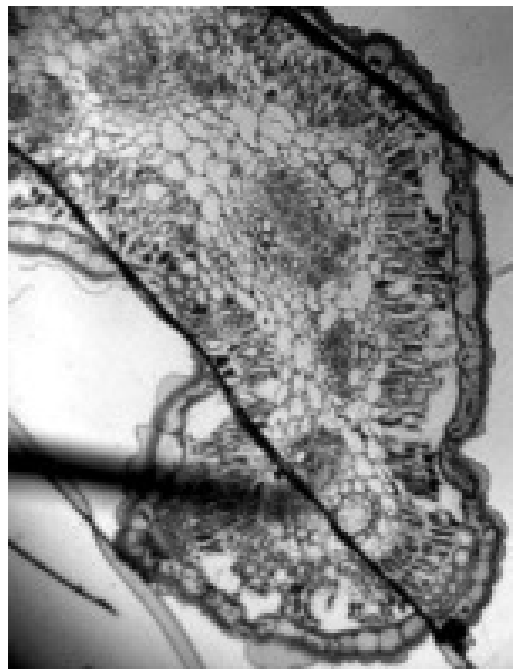

Fig. 4. The cross section of the leaf

\section{CONCLUSIONS}

1. Prangos ferulacea herb at the beginning of vegetation contains isopsoralen; $2 \mathrm{H}, 8 \mathrm{H}-\mathrm{benzo}[1,2-\mathrm{b}: 5,4-$ b']dipyran-2-one, 8,8-dimethyl-; 2-isopropenyl-2,3-dihydrofuro[3,2-g]chromen-7-one; 2-(1-hydroxy-1-methylethyl)-2,3-dihydrofuro [3,2-g]chromen-7-one; (S)-7-hydroxy-8,8-dimethyl-7,8-dihydropyrano $(3,2-\mathrm{g})$ chromen2(6H)-one; 2H-1-benzopyran-2-one, 6-(2,3-dihydroxy3-methylbutyl)-7-methoxy-; (S)-8,8-dimethyl-2-oxo-7,8dihydro-2H,6H-pyrano(3,2-g)chromen-7-yl 3-methyl-2butenoate $( \pm)$-coumarin derivatives.

2 . The coumarin composition in the freshly collected and salted Prangos ferulacea herb is identical.

3 . The structure of the glands and schizogenic spaces are diagnostic features of the anatomic structure of the plant raw material.

Conflict of Interests: authors have no conflict of interests to declare. 


\section{REFERENCES}

1. Абышев, А. З. Химия и фармакология природных кумаринов / А. 3. Абышев, Э. М. Агаев, Ю. Б. Керимов. - Баку, 2003. - С. 9-37.

2. Sajjadi, S. E. Chemical composition of essential oil of Prangos ferulacea (L.) Lindl / S. E. Sajjadi, Ya. Shokoohinia, S. Gholamzade / Roots, chemija. - 2011. - Vol. 22, Issue 3. - P. 178-180.

3. Дикорастущие полезные растения России. Практикум по ботанике / Ю. Б. Керимов, Н. А. Исламова, Д. С. Халилов, Д. И. Исаев. С.Пб., 2001. - 404 c.

4. Kafash-Farkhad, N. A review on phytochemistry and pharmacological effects of Prangos ferulacea (L.) Lindl / N. Kafash-Farkhad, M. Asadi-Samani, M. Rafieian-Kopaei / Life Sci. J. - 2013. - Vol. 10. - 8 p.

5. Флора Азербайджана. - Баку, 1955. - Т. 6. - С. 417-422.

6. Гроссгейм, А. А. Растительные ресурсы Кавказа / А. А. Гроссгейм. - Баку, 1946. - 230 с.

7. Süleymanov, T. Farmakoqnoziya praktikum / T. Süleymanov, Y. Kərimov, C. İsaev. - Baku, 2017. - 675 p.

\section{REFERENCES}

1. Abyshev, A. Z., Agaev, E. M., Kerimov, Yu. B. (2003). Khimiia i farmakologiia prirodnykh kumarinov. Baku, 9-37.

2. Sajjadi, S. E., Shokoohinia, Ya., Gholamzade, S. (2011) Chemical composition of essential oil of Prangos ferulacea (L.) Lindl. Roots, chemija, 22 (3), 178-180.

3. Kerimov, Yu. B., Islamova, N. A., Khalilov, D. S., Isaiev, D. I. (2001). Dikorastushchie poleznye rasteniia Rossii. Praktikum po botanike. S.-Petersburg, 404.

4. Kafash-Farkhad, N., Asadi-Samani, M., Rafieian-Kopaei, M. (2013) A review on phytochemistry and pharmacological effects of Prangos ferulacea (L.) Lindl. Life Science Journal, 10, 8.

5. Flora Azerbaidzhana. (1955). Baku, 6, 417-422.

6. Grossgeim, A. A. (1946). Rastitelnye resursy Kavkaza. Baku, 230.

7. Süleymanov, T., Kərimov, Y., İsaev, C. (2017) Farmakoqnoziya praktikum. Baku, 675.

Information about authors:

Kerimov Yusif Balakerim oglu, Doctor of Pharmacy (Dr. habil.), professor, scientific adviser of the Department of Pharmacognosy and Botany, Azerbaijan Medical University. E-mail: ykerimov@yahoo.com

Isaev Javanshir Issa oglu, Doctor of Pharmacy (Dr. habil.), professor, head of the Department of Pharmacognosy and Botany, Azerbaijan Medical University.

E-mail: isayev.cavanshir@amu.edu.az

Kerimli Elvin Haji oglu, senior lecturer of the Department of Pharmacognosy and Botany, Azerbaijan Medical University. E-mail: kelvin83@list.ru

Akhmedov E. Yu., Candidate of Pharmacy (Ph.D.), associate professor of the Analytical Chemistry Department, National University of Pharmacy

Відомості про авторів:

Керімов Юсіф Балакерім огли, д-р фарм. наук, професор, науковий консультант кафедри фармакогнозії та ботаніки, Азербайджанський медичний університет. E-mail: ykerimov@yahoo.com

Ісаєв Джаваншир Іса огли, д-р фарм. наук, професор, завідувач кафедри фармакогнозії та ботаніки, Азербайджанський медичний університет.

E-mail: isayev.cavanshir@amu.edu.az

Керімлі Ельвін Гаджі огли, ст. викл. кафедри фармакогнозії та ботаніки, Азербайджанський медичний університет. E-mail: kelvin83@list.ru

Ахмедов Елшан Юніс огли, канд. фарм. наук, доцент кафедри аналітичної хімії, Національний фармацевтичний університет

Сведения об авторах:

Керимов Юсиф Балакерим оглы, д-р фарм. наук, профессор, научный консультант кафедры фармакогнозии и ботаники, Азербайджанский медицинский университет. E-mail: ykerimov@yahoo.com

Исаев Джаваншир Иса оглы, д-р фарм. наук, профессор, заведующий кафедрой фармакогнозии и ботаники, Азербайджанский медицинский университет.

E-mail: isayev.cavanshir@amu.edu.az

Керимли Эльвин Гаджи оглы, ст. преп. кафедры фармакогнозии и ботаники, Азербайджанский медицинский университет. E-mail: kelvin83@list.ru

Ахмедов Элшан Юнис оглы, канд. фарм. наук, доцент кафедры аналитической химии, Национальный фармацевтический университет 